\title{
The Role of China in Africa's Industrialization: The Challenge of Building Global Value Chains
}

\author{
Mzukisi Qobo* \\ and \\ Garth le Pere**
}

\section{Disclosure statement}

No potential conflict of interest was reported by the authors

\author{
Notes on contributors \\ *Mzukisi Qobo is Associate Professor and Deputy Director at the National Research Fund Chair \\ on African Diplomacy and Foreign Policy, University of Johannesburg, South Africa \\ **Garth le Pere is Visiting Professor in the Department of Political Studies, University of \\ Pretoria, South Africa
}

\begin{abstract}
The economies of Africa require urgent structural transformation and the great challenge is how industrial development can aid this transformation process. China's ability to sustain high productivity growth was underpinned by resource allocation from low-tohigh productive sectors and this was the essence of its own modernization processes. Most African countries remain highly reliant on commodity exports in a depressed global environment, exacerbated by declining demand from China as the continent's major trading partner. This article examines the dilemmas of Africa's reliance on commodity exports but equally importantly, it seeks to investigate how China, based on its own experience, could contribute to assisting African countries to move up value chains via the imperative of a concerted industrialization endeavour and the commitments China has made in this regard. In our view, an incremental approach that takes into cognisance the importance of institution-building offers the best chance for promoting Africa's development on a sustained basis.
\end{abstract}

There is a shift in the discourse about Africa's development, with emphasis now directed at the need for the continent to undertake measures in policy and practice that would yield structural transformation. The World Economic Forum Africa Competitiveness Report defines structural transformation thus: "reallocation of economic activity away 
from the least productive sectors of the economy to more productive ones..." ${ }^{\prime 1}$ This is essentially about rise of new and more productive activities, and the shift of resources from traditional to more sophisticated and value-enhancing activities.

In the African continent, the imperative of structural transformation is driven by the realization that resource extraction has reached a point of diminishing returns, and may be limiting Africa's long-term development prospects. This is because "[i]n the product space, export items...for example, tropical agriculture, mining and oil, forest products, cereals and coffee are weakly connected to other dynamic sectors". ${ }^{2}$ In this article we explore the possibilities for Africa's industrial development beyond commodities with particular reference to China. Much of the euphoria about Africa's resurgencepopularly captured in the "Africa Rising" narrative - has been held together by a thin thread of reliance on China as a consumer of the continent's commodities. Population growth and Africa's youth bulge is another pillar that should not be viewed in a unidirectional manner because it could be a portent for social instability if its demographic dividend is not properly harnessed. Indeed, there are 200 million youth aged between 15 and 24 who possibly face a Hobbesian future of lives that might be nasty, brutish, and short in the face of lethargic indices of unemployment, inequality, and poverty.

Against this backdrop, there can be no doubt that Africa's relationship with China has provided the main gravitational pull for improving its growth prospects for nearly two decades, but in many ways it is a relationship that has restricted Africa's structural diversification. This is primarily because this relationship has not been properly grounded in a strategic trade perspective that takes account of Sino-African comparative and competitive advantages and, therefore, historically has been less informed by Africa's development exigencies than China's drive to economic growth and modernization.

The inherent asymmetries that flow from these dynamics highlight the extent to which resource extraction has developmental limits, and any dimension of external relations that is built on this shaky economic foundation is bound to subject the continent to external vicissitudes over which it has little political, policy, and managerial control. Such a fraught scenario thus has the potential to undermine Africa's long-term developmental prospects. One of the critical challenges for African countries - and this should be the basis for their engagement with external actors such as China - is managing structural change through industrial policies and value chain development in a manner that is salutary for beneficial and growth- and welfare-enhancing integration into the global economy.

1 World Economic Forum, Africa Competitiveness Report, (Geneva:WEF, 2015), p. 4.

${ }^{2}$ Mohammed Razzaque, "Industrialisation in Africa and LDCs: Some Selected Issues,"

Commonwealth Discussion Note, 2016, p. 1. 
Our key argument, therefore, is that there is a need to rethink the terms of Africa's future growth and development not only in terms of industrialization-often conceived narrowly as manufacturing-since there are fewer possibilities for the continent to undertake industrial development along a trajectory similar to earlier industrializers. Rather, going forward a strategic trade and industrial policy perspective should be the thrust of China-Africa relations in order to take advantage of the calculus of opportunity that currently exists. Thinking in terms of value-addition and value chains broadens the sectoral focus to encompass aspects of manufacturing, services, and innovation in agriculture. We do not suggest here that this should be brought to fruition through a bigbang approach. Instead the locus of Africa's relationship with China should be a policy approach that aims to promote structural diversification.

Much of this should assume what development economists Ricardo Hausmann and Bailey Klinger characterize as shifting to near 'product spaces'. Product spaces refer to a network of relations between products. ${ }^{3}$ For example, a country that has never developed a manufacturing capability but has only focused on primary agricultural products has a better chance of undertaking structural transformation by building capabilities for agroprocessing; whereas a country that already has heavy manufacturing capacity, say in the automotive sector, can move towards aerospace with relative ease than an agriculturalbased economy. Quite crucially these product spaces entail building institutional capabilities which are of utmost importance if countries are to successfully undertake structural transformation. This is all the more so given vast institutional challenges in many African countries, including infrastructure bottlenecks, low levels of human capital, and political and managerial deficiencies in guiding the process of structural change.

Thinking about Africa's development and how this could be facilitated through engagement with external actors thus requires an incremental approach that also addresses institutional constraints. Various scholars have offered rich perspectives about the importance of institutions in creating conditions that are propitious for development. Neoclassical institutionalists such as Douglas North have stressed the efficacy of institutions such as property rights in buttressing the structure of exchange through ensuring predictability and certainty in economic transactions. ${ }^{4}$ Political scientists such as Robert Rotberg have cast a spotlight on the need for the African continent to overcome infrastructural (or hard institutional) deficits so as to create a supportive environment for

\footnotetext{
${ }^{3}$ Ricardo Hausmann and Bailey Klinger, "Structural Transformation and Patterns of Comparative Advantage in the Product Space", Centre for International Development, Kennedy School of Government, Harvard University. http://www.iadb.org/res/publications/pubfiles/pubS-853.pdf/ ${ }^{4}$ Douglas C. North, Institutions, Institutional Change, and Economic Performance (Cambridge: Cambridge University Press, 1990), pp.33-35.
} 
sustained development. ${ }^{5}$ Pan Africanists such as Ali Mazrui and Francis Wiafe-Amoako have emphasized the fact that institutions underpin state stability, security and development. ${ }^{6}$ In our view, an institutionalist perspective provides an appropriate conceptual and policy anchor for Africa's relationship with external actors such as China. The very notion of an industrial policy writ large across a heterogeneous set of 54 African countries presupposes the need for institution-building.

This approach recognizes that not every African economy can be a manufacturer in the classical sense, but can at least participate in creative ways in value chains. In any case, the shape and content of manufacturing has changed globally, with horizontal integration superseding vertical integration, and with much trade in manufacturing taking the form of intermediate goods that cross national boundaries several times. This phenomenon is reinforced by services related to finance, packaging, supply chains, and logistics. Our reference to industrial development is therefore broad-based and all-encompassing including both major policy commitments and incremental processes of reform that are at the same time cognizant of institution building. Building value chains is a much more flexible and realistic approach which opens up conceptual channels linked to diversifying Africa's production base. In this article, we critically examine the terms of African countries' relationships with China, analyze their limits, and advance a view that places a premium on the diversification of African economies and their trading partners against the historical and often asymmetric backdrop of China-Africa relations.

\section{Some Conceptual and Normative Considerations}

The challenge for structural transformation is how progression along the value chain or industrial development can aid this process. Lin suggests, for example, that in the first instance countries need to design economic development strategies that are consistent with their comparative advantage. ${ }^{7}$ Rather than always thinking of taking giant leaps from one sector to another, African countries can take an incremental approach that builds on their existing comparative advantages. The conditions that Lin alludes to could be steered by governments in the context of well-functioning markets. The problem that immediately arises is that many countries of Africa lack the institutional capabilities to design such strategies and monitor their implementation. Further, their markets are generally weak, with economies dominated by the informal sector, micro-enterprises, and informal traders. If such institutional constraints are to be addressed, African countries

\footnotetext{
${ }^{5}$ Robert. I Rotberg, Africa Emerges (London: Polity, 2013), pp.116-133.

${ }^{6}$ Ali A. Mazrui and Francis Wiafe-Amoako, African Institutions (London: Roman \& Littlefield).

${ }^{7}$ Justin Yifu Lin, The Quest for Prosperity: How Developing Economies Can Take Off (Princeton: Princeton University Press, 2012), p. 78.
} 
should build the delivery of support for institution building into their external engagements.

China's ability to sustain high productivity growth was driven by resource allocation from low-to-high productive sectors and this served as the catalyst of its own structural transformation. ${ }^{8}$ Industrialization thus carries with it the promise of promoting economic diversification, inclusive growth, and a more judicious use of the continent's abundant natural and human resources. A major strategic challenge for African countries is how to translate their comparative advantage into commodity-based industrialization by adding value through its vast reserves of human capital and factor endowments. The current cyclical downturn in commodity trade again lends credence to the Prebish-Singer hypothesis about the secular tendency of terms of trade for commodities to decline over time, thus undermining any real prospect for commodity-driven economic development. ${ }^{9}$ Forging relationships with China has distinct advantages that are not often exploited by African countries. Such advantages include using these arrangements to upgrade capabilities that would allow African countries to make an incremental shift between product spaces, a move that offers a more realistic bridge-head to structural transformation. As Hausmann and Klinger point out, more capabilities (including skills, institutions, and infrastructure) enable countries to make more products, and this also lends countries latitude for diversification. ${ }^{10}$

An important component of any such strategic response has to be coherent and workable industrial policy. ${ }^{11}$ Rodrik defines this in terms of the "strategic collaboration between the private sector and the government with the aim of uncovering the most significant obstacles to restructuring and determining what interventions are most likely to remove them." 12 The challenge for African countries is that they are stuck with factor endowments that induce diminishing returns over time. Addressing these requires an incremental approach to development, and should take into account the important role of institutions. This view should underpin both industrial policies and terms of engagement with external actors such as China.

\footnotetext{
${ }^{8}$ Carsten A Holz and Tian Zhu, “Assessment of the Current State of China's Economic Reforms", in Alvin Y So, (ed.), China's Developmental Miracle: Origins, Transformations, and Challenges (Armonk: ME Sharpe, 2003), pp. 183-223.

${ }^{9}$ See Harry Bloch and David Sapsford, "Whither the terms of trade? An elaboration of the Prebisch-Singer hypothesis," Cambridge Journal of Economics, 24(4), 2000.

10 Ricardo Hausmann and Bailey Klinger, "Structural Transformation and Patterns of Comparative Advantage in the Product Space".

11 See Ha-Joon Chang, The Political Economy of Industrial Policy (Basingstoke: Macmillan Press, 1994).

12 Dani Rodrik, One Economics, Many Recipes (Princeton: Princeton University Press, 2007), p. 100.
} 
As Rodrik would argue, economic development, and diversification as its corollary, require judicious management over a range of sectors beyond comparative advantage. Such a managerial approach may begin initially with value addition of natural resources, while also developing other related streams of the economy within the product space. There is consensus in the literature on development that institutions are crucial for development. However, as Rodrik reminds us, institutional designs ${ }^{13}$ are not a given, but are context-specific. Essentially, these can be improvised and harnessed for supporting incremental steps towards structural transformation. In this context, industrial policy becomes an important instrument.

As has been argued by African policy experts: "Transformative industrial policies present an opportunity for reclaiming the policy space, as Governments can develop industrial policies that build the necessary capabilities which respond to national and regional needs, within the confines of global rules". ${ }^{14}$ This capability approach needs to feature strongly within agreements that African countries structure with external actors. Further, China-Africa relations should cover all sectors - the most strategic being manufacturing, agriculture, and services - so that there can be a gravitational pull for sustained growth and development. Otherwise viable production networks in Africa suffer because of poorly diversified and similar production structures which still show the pathological effects of the free-market orthodoxies that came with World Bank and IMF structural adjustment programs. The continental market remains limited with intra-African exports of intermediate goods accounting for only $\$ 43$ billion between 2010 and 2012. This is about 13 per cent of the $\$ 320$ billion in export value to the rest of the world. ${ }^{15}$

The intra-African market basically lacks dynamism and therefore, trade in manufactured intermediate products could be the springboard to wider and deeper economic diversification. It is estimated that Africa's changing demographic profile will demand a diversification in production structures with an emphasis on higher intensity employment activities: in short 10 million new jobs in the formal sector are required each year in order to absorb a burgeoning youth population who will enter the job market. This highlights the importance of investments in human capital, especially in education, skills training, and health. Resources for diversification could also be freed up through "smart protectionism" measures which include the strategic use of tariffs, subsidies, local content requirements, technology transfer provisions, and strategic foreign direct

\footnotetext{
${ }^{13}$ Dani Rodrik, "Growth Strategies", John F. Kennedy School of Government, Harvard University. http://drodrik.scholar.harvard.edu/files/dani-rodrik/files/growthstrategies.pdf?m=1435073927/

${ }^{14}$ Carlos Lopes, "Introduction" in UN Economic Commission for Africa, Transformative Industrial Policy for Africa (Addis Ababa: UNECA, 2016), p. 3.

${ }^{15}$ UN Economic Commission for Africa, Economic Report on Africa: Industrializing through Trade (Addis Ababa: UNECA, 2015), p. 16.
} 
investment which fall outside of the remit of the World Trade Organization and other trade and investment agreements. ${ }^{16}$

It is at this interface where China could play a major role in promoting trade-related industrialization as the continent's largest trading partner, coupled with its ability to transfer technology and skills. An important development has been the activation in early January 2016 of the China-Africa Industrial Capacity Cooperation Fund by China's central Bank, The People's Bank of China. The Fund has an initial capitalization of \$10 billion to promote manufacturing, high and new technology, agriculture, energy, infrastructure, and development finance. ${ }^{17}$ And in what could be salutary for Africa, at the September 2016 meeting of G20 leaders in Hangzhou, the Initiative on Supporting Industrialization in Africa and Least Developing Countries was launched. Importantly and among others, the initiative focuses on supporting agro-industry; broadening production bases; investing in secure energy; developing resilient infrastructure; leveraging domestic and international finance; and promoting science, technology and innovation. ${ }^{18}$ These developments take on added significance because of Africa's marginal position in global trade: while the continent's share of global exports increased negligibly from 4.99 per cent in 1970 to 5.99 per cent in 1980, it was down to 3.3 per cent in 2013. A coherent industrial strategy that is institutionally pragmatic, adaptive, and calculating in moving African economies up regional and global value chains promises to significantly improve Africa's prospects for economic diversification and ex hypothesi, it share of global exports. ${ }^{19}$

In what is instructive for industrial policy, Nigeria's Finance Minister Ngozi OkonjoIweala has drawn on her personal experience in driving economic reforms in Nigeria since $2003 .{ }^{20}$ She highlights the following steps as critical for turning failing countries around:

- managing public finances better through transparency and tighter fiscal management;

- deregulating backbone infrastructure sectors, in particular telecommunications;

- setting up institutions aimed at fighting corruption;

- locking-in legal reforms to prevent reversals; and

\footnotetext{
${ }^{16}$ UNECA, Transformative Industrial Policy for Africa, pp. 34-40.

${ }^{17} \mathrm{Ni}$ Yanshuo, "Promoting Clarity: China-Africa Industrial Cooperation," ChinAfrica, 8, April 2016, p. 27.

18 See G20 Leaders' Communique: Hangzhou Summit, 4-5 September 2016, paragraph 35. http://G20.org/English/Dynamic/201609/t20160906_3396.html/

${ }^{19}$ See, for example, Ricardo Haussman and Dani Rodrik, "Economic Development as Self Discovery," Journal of Development Economics, 72(2), 2003.

${ }^{20}$ Ngozi Okonjo-Iweala, Reforming the Unreformable: Lessons from Nigeria (Cambridge: Massachusetts: MIT Press, 2012), pp. 119-122.
} 
- reorienting policy to focus on job creation, in particular in the real sectors of the economy.

This is an approach that confirms the importance of home-grown measures in managing economic change in African countries. These are especially important macro-economic measures as a prelude to sectoral strategies that could support economic diversification. It is important that macro-economic reforms are strongly complemented with microeconomic interventions, in particular those aimed at diversifying the economic structure; improving human capital; and achieving greater inclusion of marginalised people in the economy.

\section{A Review of China-Africa Economic Relations}

China has been the primary consumer of African commodities, and a major source of financing for Africa's infrastructure. On the surface, China's feat in making a transition from a backward to a modern economy in just a little over three decades has made it an attractive model for other developing countries. Its ability to lift 680 million people out of poverty between 1981 and 2010, and reducing extreme poverty rate from 84 percent in 1980 to 10 percent in 2015, is nothing short of extraordinary. ${ }^{21}$ It is this achievement which raised hopes that, perhaps, stronger commercial engagement between China and Africa would generate the necessary momentum for Africa's prosperity. All the more so since the Chinese leadership has been careful not to project a big brother image towards Africa. It has tempered its commercial engagement with an emphasis on notions of mutual respect and solidarity.

The Forum on China-Africa Cooperation (FOCAC) is the institutional expression of the relationship between the two although it is asymmetric in the sense that China crafts the agenda, sets priorities, and provides all the cooperation funding. However, since its establishment in 2000, it is only recently that FOCAC is gaining real significance because China always preferred bilateral engagement in the pursuit of its commercial interests. ${ }^{22}$ China made the most far-reaching and consequential commitments at the sixth FOCAC summit held in South Africa in December 2015. There President Xi Jinping announced a $\$ 60$ billion package for financing ten major initiatives. This included $\$ 10$ billion for a fund dedicated to building industrial capacity and investment in manufacturing, hi-tech, agriculture, energy and infrastructure. In addition, there was $\$ 5$ billion for aid and interest free loans and $\$ 35$ billion for export credits and preferential loans.

\footnotetext{
${ }^{21}$ Mel Gurtov, "China’s Third World odyssey: Changing priorities, continuities, and many contradictions," in Carla P Freeman, (ed.), Handbook on China and Developing Countries (Cheltanham: Edward Elgar Publishing, 2015), p. 75.

${ }^{22}$ See Garth Shelton, Funeka Yazini April and Li Anshan, (eds.), FOCAC 2015: A New Beginning for China-Africa Relations (Pretoria: Africa Institute of South Africa, 2015), pp. 7-12.
} 
The FOCAC process has been underpinned by a surge of foreign direct investment from China into the African continent. Many countries have seen an expansion of infrastructure in roads, airports, telecoms, hospitals, and ports while trade linkages between China and Africa have deepened, thereby helping to create alternative markets for African countries. However, the Chinese focus has been mainly on investment in commodities, particularly oil, gas and metals which accounted for two-thirds of Africa's exports to China by value in 2014 while there are very few countries where sustained manufacturing activities take place.

According to Chen et. al, by the end of 2013, Chinese foreign direct investment in Africa topped $\$ 26$ billion compared to Chinese FDI in the US at $\$ 22$ billion. This amply demonstrated the seriousness with which the Chinese regard Africa as a strategic arena for exercising their commercial diplomacy. ${ }^{23}$ Many African leaders thus view China as a dependable partner. However, much of Africa's exports to China comprise low valueadded commodities, whereas African countries import relatively higher value-added and manufactured products from China, including capital and consumer goods. This relationship is also deficient in institutional components, and so far has not focused on upgrading the capabilities of African partner countries.

\section{China's Pragmatic Approach}

Notwithstanding the recent slow-down of China's economy, Africa still retains its geopolitical importance in China's strategic foreign policy calculus. While commodity demand remains depressed, China still seeks to extract trade and commercial advantage from an African market of more than 1 billion consumers with fast changing tastes and demands. On the basis of the 'One China' policy, China has been able to prove its bona fides as a trusted development interlocutor on the basis of providing instrumental benefits such as grants, zero-interest loans, development finance and investment, and substantial debt relief. China has thus been guided by dynamics of 'state-led pragmatic nationalism' in Africa which is "ideologically agnostic, having nothing, or very little to do with either communist ideology or liberal ideals. It is firmly goal-fulfilling and national interest driven... The country's strategic behaviour is flexible in tactics, subtle in strategy, and avoids appearing confrontational". ${ }^{24}$ This flexibility and subtlety has been powerfully

\footnotetext{
${ }^{23}$ Wenjie Chen, David Dollar and Heiwai Teng, "Why is China investing in Africa? Evidence from the firm level", Brookings Institute Paper, August 2015. http://www.brookings.edu/ /media/research/files/papers/2015/08/why-china-is-investing-inafrica.pdf/

${ }^{24}$ Suisheng Zhao, "China's Geo-Strategic Thrust: Patterns of Engagement", in Garth le Pere, (ed.), China in Africa: Mercantilist Predator or Partner in Development? (Johannesburg and
} 
expressed in the partnership that China forged with the World Bank recently to form a joint infrastructure firm to fund projects in Africa, especially to bring those projects to commercial viability that have not reached bankability. ${ }^{25}$

That said and from a commercial point of view, apart from seeing Africa as a supplier of commodities, China regards the African continent as an underdeveloped market for lowtechnology and cost-effective manufactured goods and services. Furthermore, Africa also presents an opportunity for China to access markets like Europe and the United States due to the preferential access into those markets granted to less developed countries, especially in the case of textiles and apparels. ${ }^{26}$

While China overtook the US as Africa's single largest trading partner in 2009, with the value of trade rising from $\$ 10$ billion in 2000 to top $\$ 300$ billion in 2015 . From a low of 2.3 per cent in 1995 , China now accounts for 24 per cent of Africa's total trade. ${ }^{27}$ However, much of the two-way trade has been skewed in China's favor. The only exceptions to this general rule have been resource-rich countries such as Angola, the Republic of Congo, the Democratic Republic of Congo, Zambia, and Equatorial Guinea, which have sustained trade surpluses on the back of their bulk exports of raw materials. ${ }^{28}$ African companies therefore face major operational hurdles related to their inability to locate themselves within Chinese value chains. This helps to explain why Africa's trade with China has hardly contributed to export diversification and economic transformation.

Indeed, as much as 87 per cent of China's exports to Africa consist of equipment and machinery, textiles and clothing and other manufactured products. China is also interested in Africa's labor market since the continent boasts a large reservoir of untapped labor resources, making it an ideal location for China's labor-intensive industries. ${ }^{29}$ This relationship could be substantially enriched if it includes the imperative of helping African countries develop viable institutions and product spaces.

Midrand: The South African Institute of International Affairs and the Institute for Global Dialogue, 2007), p. 39.

25 "China and World Bank form firm to fund Africa projects", Daily Nation, 12 September 2016. http://www.nation.co.ke/business/China-and-World-Bank-form-firm-to-fund-Africa-projects/9963377898-yr4a69/

${ }^{26}$ Mills Soko and Mzukisi Qobo, "The Role of the BRIC in Africa's Development: Drivers and Strategies," Journal of Contemporary History, Vol. 41 (1), 2016 pp. 80- 102.

${ }^{27}$ China Daily, 11 October 2015. www.chinadaily.com.cn/business/201511/10/content_22417707:html/

${ }^{28}$ Paulo Drummond and Liu Xue, “Africa's rising exposure to China: How large are spillovers through trade?" Washington DC: IMF Working Paper. WP 13/250, November 2013.

${ }^{29}$ Yun Sun, "Africa in China's foreign policy”, paper prepared for the John L Thornton China Centre and Africa Growth Initiative: Brookings Institute, Washington DC. April 2014, p. 6. 
It needs underlining that China still retains self-reference as a developing country, in part to emphasize the reality that the project of modernizing its economy and bridging the rural-urban divide is far from complete. Millions of Chinese still live under poverty and the country has the second largest number of poor people in the world after India. ${ }^{30}$ Also importantly, China seeks to avoid the spotlight on itself as a fast industrializing economy and a global actor. It is uncomfortable with any differentiation from other developing countries. The Chinese are also wary of the demands placed upon it by Western countries to play a bigger role as a responsible stakeholder and co-shoulder the burden of managing the international system. $\mathrm{Tu}$ and Mo note that this is regarded by the Chinese as a containment strategy by the West. ${ }^{31}$

However, it is inevitable that China will sooner or later have to content itself with the reality that it is unlike other developing countries: the sheer size of its economy and position in the international trading system makes it a global player of note. Zheng Bijian, an advisor to the Chinese leadership, tried to burnish China's low-income developing country status to a Western audience in 2005 by refusing to seize the opportunity to gloat about the impressive growth rates China was notching up at the time. ${ }^{32}$ This global role has a fortiori come into greater prominence with China's Belt and Road initiative which was unveiled in 2013, and whose ambition is to expand land and sea linkages between Asia, Africa, Europe, and beyond. The initiative rests on massive and unprecedented investments in infrastructure, manufacturing, and services as the essential means of giving these links real substance and boosting trade among participating countries. Already, China commits $\$ 150$ billion annually to the 68 countries that participate in the project. $^{33}$

In the first major Summit - called the Belt and Road Forum - held in Beijing from 12-15 May 2017 and attended by leaders from 29 countries, President Xi pledged \$124 billion to further develop interlocking economic and investment partnerships with the intention for China to import $\$ 2$ trillion in products over the next five years from countries that are engaged in the initiative. Moreover, it is expected that the active use of local currencies will assist in mobilizing domestic savings, lower remittance and exchange costs, and safeguard financial stability.

\footnotetext{
${ }^{30}$ Xinquan Tu and Huiping Mo, "China's developing country identity-challenges and future prospects," in Carla P Freeman (ed.), Handbook on China and Developing Countries, p. 89. 
This is part of China's grand ambition to assume a mantle as a leading champion of globalisation that is more integrative and uses infrastructure networks to connect various continents. African countries, which hitherto have been on the margins of globalisation, are also drawn into this new orbit of power and perceive developmental benefits on the back of this mega-infrastructure drive. African countries such as Kenya, Egypt, and Ethiopia participated at the launch in May 2017. Many African countries have already built experience with the Chinese on various infrastructure projects, mainly spanning road and rail projects.

\section{Current Reform and Structural Challenges Confronting Africa}

It is widely recognized that Africa's impressive economic growth between 2000 and 2007, just before the global financial crisis, and the years following it, was reinforced by China's industrial growth and its insatiable demand for commodities. Since 1995, the African continent has registered rapid economic growth and development against the backdrop of both a commodities' boom and expanding investment in a diverse range of sectors, from natural-resourced based industries to wholesale, retail, trade, telecommunications, and manufacturing. This picture was to change in the second half of 1995, when African economies began to enter a period of low growth as a result of fall in commodity prices, and a generally subdued global economic outlook. ${ }^{34}$

The slump in commodity prices in the latter half of 2015 has had a severe effect on Africa's macro-economic environment, with oil-rich countries such as Angola and Nigeria feeling the brunt. In a country like Angola, for example, oil makes up roughly 90 percent of exports. Angola had an average growth rate of 10.8 percent from 2005 to 2013; however in 2015 growth declined markedly to 3.5 percent, and it may take time for the country to enjoy growth rates above 5 percent again. Nigeria is heavily dependent on oil and this narrow production and export base is among key factors constraining its trade expansion, and possibly its long-term development. ${ }^{35}$

Beyond oil, the hardest hit commodities include iron ore, copper and platinum - all of which have in the past been in great demand in China. Thus countries such as Ghana, Zambia and South Africa were also affected by the economic slump in emerging economies, especially due to weak mineral prices. On the other hand, Ethiopia, Mozambique and Kenya, which are less dependent on minerals, are generally viewed as

\footnotetext{
${ }^{34}$ See Angus Deaton, "Commodity Prices and Growth in Africa," Journal of Economic Perspectives, Vol. 13 (3) Summer, 1999, pp. 23 - 40.

${ }^{35}$ Ngozi Okonjo-Iweala, Reforming the Unreformable: Lesson from Nigeria, (Cambridge, Massachusetts: MIT Press), 2012, pp. 20 - 21.
} 
potential star performers in the continent because their growth has been less affected by the softening of commodity demand in emerging economies.

In the case of Kenya, for example, consumer spending has been one of the main drivers of growth. ${ }^{36}$ Sectors such as manufacturing, infrastructure, and agriculture underpin buoyant economic activity. The countries that have been badly exposed to poor external market conditions are those that are dependent on commodity exports. As an Atlantic Council Report on Africa remarked: "Countries that are not reliant on commodities are better off in the current market conditions than their commodity dependent counterparts". 37

Africa's dependence on China for its exports has not been entirely healthy. China's GDP grew at 6.9 percent in 2015, down from 7.3 percent in 2014, and is expected to experience further decline to 6.3 percent in $2016 .{ }^{38}$ Sectors such as manufacturing, construction, and real estate, which have in the past soaked up Africa's commodities, have witnessed a slump. Africa's business cycle has in the past two decades been tightly aligned to that of major emerging economies, especially China, and this coupling has proven to be a fetter on Africa's industrialization prospects. According to a recent International Monetary Fund paper assessing Africa's exposure to China, 1 per cent growth in China's real fixed investment growth is associated with a 0.6 per cent increase in sub-Saharan Africa's exports. ${ }^{39}$ This dependence could have deleterious consequences for Africa's long-term prospects. China, as Ali Zafar notes, exerts an indirect effect on economic management in Africa, especially because it is a global price setter. ${ }^{40}$

The disruptive effects of China's engagement with Africa are critically assessed by le Pere. ${ }^{41}$ A particular concern noted by him is the extent to which China has stifled other developing countries from fully shifting up the regional and global value chains. This is not to suggest that the adverse change of Africa's economic fortunes is entirely attributable to the Chinese. To be sure, there are a number of internal factors that have stunted Africa's growth and development. For Rodrik, “...growth in developing nations

${ }^{36}$ UN Conference on Trade and Development, Economic Report on Africa: Dynamic Industrial Policy in Africa. (Geneva: UNCTAD, 2014) p. 7.

${ }^{37}$ Peter J Pham and Aubrey Hruby, "Embracing Impact: How African Can Overcome the Emerging Market Downturn". The Atlantic Council Africa Centre. Issue Brief. April 2016. p. 92. http://www.atlanticcouncil.org/programs/africa-center/publications/

${ }^{38}$ International Monetary Fund, World Economic Outlook. (Washington DC: IMF, January 2016). http://www.imf.org/external/pubs/ft/weo/2106/update/01/

${ }^{39}$ Paulo Drummond and Liu Xue, "Africa's rising exposure to China”, op. cit..

40 Ali Zafar, "The growing relationship between China and Sub-Sahara Africa: Macro-economic, trade, and aid links", The World Bank Research Observer. 22(1), 2007, p. 108.

${ }^{41}$ Garth le Pere, "The China-Africa Connection: an ambiguous legacy?" in Carla P Freeman, (ed.), Handbook on China and Developing Countries. p. 368. 
is held back by a variety of country-specific obstacles - ranging from weak institutions to poor geography, from lousy policies to poverty traps". ${ }^{42}$ Insufficient hard and soft infrastructure are identified by Lin as major barriers to productivity growth. Other reform measures are required at the macro-economic level to support economic activity and promote competitiveness. ${ }^{43}$ China's competitive edge has been honed on the basis of key factors such as low unit-labor costs, a surfeit of subsidized credit, and an undervalued exchange rate. Moreover, its total factor productivity has been enhanced by its accession to the WTO in 2001 and aggressive reform of its state-owned enterprises.

The recent rise in China's labor costs and the appreciation of its currency provide African countries with the strategic momentum to attract more investments from China as well as from developed countries As China rebalances its economy in favour of greater capital intensity, it is estimated that it will shed more than 85 million manufacturing jobs. ${ }^{44}$ Africa could become the strategic locus for the 'offshoring' of these jobs provided it can respond to the relevant institutional and policy challenges that come with this opportunity.

On balance China's contribution to Africa has been positive, especially since it has boosted growth and national incomes. This, however, comes up against an incontrovertible reality that China has not helped Africa move into patterns of sustained industrialization in order to generate broad-based prosperity. This move, we argue, could take the form of incremental adjustments when it comes to institution-building and stimulating shifts within product spaces, as a basis for integration into the value chains. So far, this relationship has fostered different forms of dependence which have accentuated Africa's static comparative advantage in commodities. As le Pere asserts, "...China's patterns of trade with Africa replicate and reproduce forms of neo-colonial structural dependence, which treat the continent as a commoditized periphery". ${ }^{45}$ In terms of the Prebisch-Singer hypothesis, primary commodities are highly susceptible to price fluctuations, with adverse effects on foreign exchange earnings.

According to Frieden: "The colonial political economies had relied on exporting primary products to the mother country: copper from Congo to Belgium, coffee from Kenya to

\footnotetext{
${ }^{42}$ Dani Rodrik, "An African Growth Miracle”, The $9^{\text {th }}$ Annual Richard H Sebot Lecture. Centre for Global Development. 14 April 2014

${ }^{43}$ Justin Yifu Lin, The Quest for Prosperity: How Developing Economies Can Take Off. (Princeton: Princeton University Press, 2012). p. 172.

44 Lynn Noah, "Slowdown in Manufacturing Sector Forces China to Shift its Focus," Market Realist, 1 March 2016. www.marketrealist.com/2016/03/slowdown-manufacturing -sector-forceschina-shift-focus/

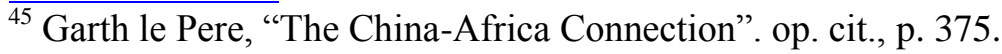


Britain, cocoa from Cote d'Ivoire to France, petroleum from Angola to Portugal."46 Nothing much seems to have changed in Africa's trade patterns with China. It is a relationship that has not helped African countries to build sustainable regional value chains and integrate beneficially into global markets. There is an opportunity for China to undertake a different approach to its relationship with Africa. Hints of this emerged at the $6^{\text {th }}$ FOCAC summit where President Xi identified five pillars that would underpin the future of China-Africa cooperation, namely, mutual political trust; solidarity in international affairs; economic cooperation; greater sincerity and friendship; and mutual security assistance. In a normative sense at least, these pillars together with the broadening ambit of cooperation contained in the ten major FOCAC initiatives for 20152018 provide the ingredients for long-term sustainability, but this can only be ensured through institution building and enabling African countries and regions to make incremental shifts in the relevant product spaces.

\section{China's New Normal and Prospects for Africa's Development}

China's credit downgrade by Moody's during May 2017-the first since 1989 and much to the chagrin of the country's mandarins - signaled an even tougher adjustment period ahead. Before then the Atlantic Council Report had noted that: "As China's growth slackens, its interest in and ability to finance African projects - and especially valuable infrastructure - will necessarily slow, causing African governments to have to rethink their infrastructure development". ${ }^{47}$ Moody's downgrade is symptomatic of China's economic vulnerabilities, especially with regard to a rising government debt-burden of around 40 per cent of GDP by 2018, and with growth slated to decline to 5 per cent by the end of this decade. It would seem, therefore, that China's historic and sustained high growth moments might be something of the past.

Chinese President Xi Jinping remarked recently that China's economic slow-down and the rebalancing of the economy away from debt-fuelled investment in infrastructure and heavy industry signaled a "new normal" for China. This should be a warning for Africa. The economic slowdown in emerging economies, China's internal economic restructuring, and new priorities to reposition China in the global economy have meant a shift of focus away from commodities and a growing orientation towards consumption, services, and innovation - all of which will require de-emphases on imports from elsewhere, not least from African countries ${ }^{48}$ There could be new opportunities in this shift for the African continent, especially as already mentioned to pick up low-end

${ }^{46}$ Jeffrey Frieden, Global Capitalism: Its Fall and Rise in the Twentieth Century. (New York: WW Norton, 2007). p. 450.

${ }^{47}$ Peter J Pham and Aubrey Hruby, "Embracing Impact." op. cit, p.92

${ }^{48}$ See International Monetary Fund, World Economic Outlook: Update, July 2016. https://www.imf.org/external/pubs/ft/weo/2016/update/02/ 
manufacturing that could likely result from China's shift towards the higher end of the value chain.

The relationship between China and Africa may likely undergo re-adjustment notwithstanding the FOCAC commitments. The shape of such a change is not easy to discern at this stage. What is apparent is that the shift from investment and exportorientation in China will have an impact on the African continent. If African countries were to be beneficiaries of China's export-led growth model, the reverse of this model is unlikely to have a neutral effect on the African continent. Our contention is that this relationship should move beyond products that are of interest to the Chinese market, and that focus narrowly on static comparative advantage, to building incremental institutional capabilities.

This is not to say China will not require Africa's commodities, but that this will occur to a far lesser extent than was the case in the past, precisely because China's future development trajectory is shifting. Certainly, as China moves up the value chain, with emphasis on industrial upgrading, a consumption drive, expansion of services, and a clean environment, it will not make as much use of the continent's commodities concerning inputs into its fixed domestic investment. ${ }^{49}$ Yet, the China-Africa relationship will remain important but probably on redefined terms. China's Belt and Road initiative could offer African countries an opportunity to redefine this relationship on the basis of a re-defined development consensus that could potentially facilitate their integration into the global economy in a more consequential and thus welfare-enhancing manner. This recalibration should position China as self-enlightened and long-term oriented in harnessing Africa's potential with a focus on developing its institutional capabilities, diversifying its production base, and integrating beneficially into the global economy. It therefore behooves African countries to use this opportunity to shift their focus from resource rents to recasting their external strategies through home-grown methodologies of industrial development. Dependence on China, especially for the export of primary products, certainly has a proven constraining effect.

Addressing the Bao Forum in April 2016, the Chinese Premier Li Keqiang stressed China's renewed emphasis on innovation as the key to development. He further stressed human capital, R\&D investment, and advancing what he referred to as "the new economy and shared economy" that is "...guided by the new visions of innovative, coordinated,

${ }^{49}$ Miria Pigato and Wenxia Tang, "China and Africa: Economic Ties in an Evolving Global Context," op. cit. pp. 21-22. 
green, open, and shared development" ${ }^{50} \mathrm{He}$ underlined the emerging contours of the Chinese economy, namely, that structural adjustment is underway, with consumption and services as the main drivers of growth in China, coupled with assertive attempts to deal with energy intensity and the discharge of pollutants from industrial activity.

The thrust of the $13^{\text {th }}$ Five-Year Plan is to rebalance the Chinese economy away from its heavy manufacturing export-orientation that relies on commodities. Given China's clear indication that it intends focusing its resources on the upper end of the production value chain, there could well be opportunities for relocation to Africa of those segments of manufacturing that depend on low-skilled labor due to increased productivity gains in China and a rise over time of the real exchange rate relative to Africa. Technology and capital transfer would help to boost Africa's real transition from commodity dependence to manufacturing. ${ }^{51}$

\section{Which way forward for Africa?}

As far as Africa's future is concerned, it remains difficult to ascertain the exact impact of the economic slowdown in emerging economies and the internal restructuring in China. Many African countries will respond differently to these developments. Those that have been undertaking reforms, investing in infrastructure, and diversifying their economies are likely to withstand the headwinds, and possibly be in a better position to chart a promising future. A brief survey of a selection of diverse African economies may offer some clues.

A country like Mozambique, for example, has mega-projects and large infrastructure investments that are financed through FDI and government. The economy was projected to grow at 7.5 per cent in 2015 and to continue to perform well in 2016 and beyond. ${ }^{52}$ The sectors that have shown positive signs include construction, services to enterprises, transport, communications, the financial sector, and gas. There is no reliance here on extractives only, but there is a range of services sectors which help to drive economic performance. Apart from its gas fields, Mozambique has also embarked on regional spatial development initiatives programmes, anchored on large public projects under the auspices of the World Bank.

\footnotetext{
${ }^{50}$ Li Keqiang, "A New Vision for a Dynamic Asia Through Joint Efforts," Speech at the opening plenary of the Bao Forum for the Asia Annual Conference. 24 March 2016. http://news.xinhuanet.com/english/2016-03/26/c 135224412.htm/

${ }^{51}$ Derek Anderson, Jorge Ivan Canales Kriljenko, Paulo Drummond, Pedro Espaillet and Dirk Muir, "Spillovers from China onto Sub-Saharan Africa: Insights from the Flexible System of Global Models", Washington DC: IMF Working Paper. WP/15/221. 2015. p. 25.

${ }^{52}$ African Development Bank, African Economic Outlook 2015, (Abidjan: AfDB), 2015.
} 
This programme established growth poles, and sought to inject dynamism in key economic corridors such as Zambezi, Tete, Sofala, Niassa, Nampula, Maputo City, and Manica province. However, all these positive developments could be undone as the country faces an onerous debt burden of $\$ 11.64$ billion and a financial crisis as government-guaranteed loans fail. In the latter half of 2015, Mozambique showed signs of growing fragility due to a combination of political tensions between the governing Frelimo party and the Renamo opposition. The country's dire economic condition was compounded by regional drought and the rapid decline in commodity prices. Foreign Direct Investment fell by 24 percent; while growth decelerated to 6.3 percent, the lowest since 2009. ${ }^{53}$ Furthermore, Mozambique has had to request a loan facility of $\$ 282.9$ million from the IMF in order to build up its reserves and ensure macro-economic stability. ${ }^{54}$

Nigeria's non-oil sector has in recent times been the main driver of growth, with services contributing about 57 per cent to the economy; manufacturing 9 per cent, and agriculture 21 per cent. Government's economic development strategy has a strong focus on building the non-oil sector. In its Vision 2020, Nigeria sets out to promote an open, market-based economy that prioritizes sectors such as ICT services, telecoms equipment manufacturing, building ICT industry clusters, improving the performance of the agricultural sector, increasing manufacturing value-added as a proportion of the GDP, and improving the finance sector. ${ }^{55}$

The share of services in Nigeria's economy has doubled since 2008. This is a story that is common across the continent, especially outside of resource-dependent economies. In Nigeria, services-related sectors include retail, wholesale trade, real estate, and information and communications technology. Nigeria's economy has been on a reform path for the past 10 years, with proposed special industrial zones to promote clustering of manufacturing activities. Nigeria is positioning itself as a preferred investment destination for labor-intensive manufacturing, riding on the wave of China's rising labor costs. However, it has been hard-hit by the decline in commodity prices, and its fiscal position has been significantly compromised. However, Nigeria has not escaped the global headwinds. The impact of slower economic performance in emerging economies was particularly severe in 2015 and the rebalancing of China's economy has been hard-

\footnotetext{
${ }^{53}$ World Bank, Mozambique Economic Update: Navigating Low Prices, (Washington D.C: World Bank), 2016. http://documents.worldbank.org/curated/en/698961467989521291/pdf/105088-BRI-ADDSERIES-P156495-Mozambique-Economic-Update-March-2016-EN.pdf

${ }^{54}$ International Monetary Fund, Mozambique: Staff Report for the 2015 Article IV Consultation, IMF Country Report No. 16/9 http://www.imf.org/external/pubs/ft/scr/2016/cr1609.pdf

${ }^{55}$ African Development Bank, African Economic Outlook 2015, (Abidjan: AfDB), 2015.
} 
felt in the oil-dependent Nigeria. Low oil prices have exerted intense downward pressure on government revenues, and triggered macro-economic imbalances. ${ }^{56}$

Kenya's demographic profile is potentially a catalyst for dynamic growth, driven by growing entrepreneurship, a domestic consumer base, and a middle class that is a source of human capital in the public service and the private sector. Kenya's growth is mainly supported by expansion in construction, manufacturing, finance, insurance, ICT, wholesale, and retail trade. There has been a drop in tourism receipts in recent times as a result of terrorism attacks. However, overall economic performance has been impressive. ${ }^{57}$

With a population of 88 million, and ranked among the five fastest growing economies in the world, Ethiopia has also shown great economic potential in the past five years. It is expected to grow at more than 8 percent in 2016 and 2017. ${ }^{58}$ The key drivers are industrialization and manufacturing, having succeeded to attract foreign direct investment into sectors such as textiles and shoes. Here, the Chinese Hujian Group has made an important contribution in building the leather value chain when it opened its shoe production factory as part of establishing a \$2 billion Special Economic Zone (SEZ) that would absorb nearly 100000 workers. The SEZ is earmarked to be a manufacturing platform for export production to global markets.

Further, Ethiopia's improved economic performance has taken place on the back of prudential fiscal policies, and broad macro-economic stability. The country is highly rated on economic inclusion in comparison with countries that notched average growth above 6 per cent from 2001 to $2014 .^{59}$ It has experienced some structural transformation that has witnessed a decline in the share of agriculture in the GDP, while services and industry have expanded. Its economy has generally experienced balanced growth across various sectors in 2013/2014: agriculture represents 42.2 per cent of the GDP, and has grown by 5.4 per cent; industry registered 14 per cent of the GDP, and grew by 21.2 per cent; and services share was 47.2 per cent and rose by 5.6 per cent. ${ }^{60}$ Some accounts suggest that Ethiopia could reach middle income status by $2025 .{ }^{61}$

\footnotetext{
${ }^{56}$ International Monetary Fund, Nigeria: Staff Report for the 2015 Article IV Consultation, IMF Country Report No. 16/101, April 2016.

${ }^{57}$ African Development Bank, African Economic Outlook 2015, (Abidjan: AfDB), 2015.

${ }^{58}$ IMF World Economic Outlook, "Subdued Demand, Diminished Prospects", January 2016. http://www.imf.org/external/pubs/ft/weo/2016/update/01/

${ }^{59}$ African Development Bank, African Economic Outlook 2015, (Abidjan: AfDB), 2015.

${ }^{60}$ Africa Economic Outlook 2015.

${ }^{61}$ World Bank, Ethiopia Economic Update: Laying the Foundation for Achieving Middle Income Status, 18 June 2013. http://www.worldbank.org/en/news/press-release/2013/06/18/ethiopiaeconomic-update-laying-the-foundation-for-achieving-middle-income-status
} 
However, the Ethiopian market remains relatively closed to foreign investors and to imports, as the government pursues a largely inward-looking trade and industrial policy. Nonetheless, as the country's World Trade Organization accession negotiations move towards their conclusion, so policy will become more outwardly focused, most likely on the East African Community in the first instance but also towards the world.

These country snap-shots highlight two major sectoral dynamics: one is the challenge of agriculture and the other is the promise of services. The potential of agriculture in Africa remains largely untapped while its regional value chain offers strategic scope for inclusive growth as well as wealth and job creation through specialization and diversification. Despite numerous pan-African programmes and external support measures, African governments have not been able to make the necessary interventions to turn the continent into a net exporter of food, fibre, beverages, and key agro-inputs, especially at a time when many African countries are experiencing food insecurity.

While intra-African trade in agriculture has been liberalized through lower tariff levels, small farmers still face challenging entry barriers, compounded by lack of technology, logistical support, and capital. This has a lot to do with Western transnational firms such as Nestle, Unilever, Mondelez International, Danone, and Archer Daniels Midland dominating regional food, fibre, and beverage value chains in Africa. There is thus a need for African governments and donors to scale up public spending on agriculture infrastructure and technologies so as to encourage efforts and policies that promote local and regional agro-industries and production chains. ${ }^{62}$

The services sector has been a critical vehicle in the GDP growth of many African countries besides attracting FDI and being a major link in developing value chains. In 2013, services accounted for 81 per cent of GDP in Seychelles; 77 per cent in Djibouti; 71 per cent in Mauritius; 69 per cent in South Africa; 61 per cent in Botswana; and 60 per cent in Senegal. In short, services have been the main contributor to GDP in 35 out of 54 African countries. Competitive firms and a healthy business environment require a range of services such as infrastructure, finance and banking, hotels and tourism, aviation, insurance and so on. In addition services in health, education, water and sanitation are also vital for social and human development.

In 2012, services attracted 40 per cent of FDI across Africa compared to 24 per cent in 2011. The services sector in Africa has benefited in particular from the interest shown by private equity in business services, information technology, industrial products, telecoms and media. Services have also shown increasing levels of employment due to their labor intensive nature and the value-added in services has grown appreciably in economic

62 UNECA, Industrializing Through Trade, pp. 105-109. 
development over the last decade, especially in travel (40 per cent), transport ( 25 per cent), and commercial services (23 per cent). Services thus offer an opportunity for much needed structural transformation across Africa. ${ }^{63}$

As the Chinese experience amply demonstrates, a strong case can be made for the virtues that could accrue from Africa's participation in regional and global value chains since these open up potential avenues for industrial development. The importance of segmented value chains come into play since they allow African countries to engage in international trade as part of specific stages of the production process which helps to exploit comparative advantages. Here, the importance of the service sector and FDI must be emphasized for the impetus they provide in expanding trade. China can provide the necessary skills and technology via the FOCAC process, especially in the production of intermediate goods which account for nearly 60 per cent of Africa's total merchandise imports and over 80 per cent of its exports. Intermediate goods thus represent the most dynamic dimension of Africa's merchandise trade but this still accounts for only 2-3 per cent of the global figure. ${ }^{64}$

Moreover and building on their joint experience in the FOCAC process, there is an opportunity for African countries to integrate Belt and Road funding into their own development needs and processes, especially with regard to industrial growth and infrastructure investment. This will entail proactive interaction with the Chinese to establish what synergies exist, making the necessary contractual and investment commitments, and putting in place monitoring and evaluation mechanisms to ensure winwin gains. ${ }^{65}$ The challenges which this entail brings us back to a major structural impediment, namely, that African producers are mainly linked to global value chains as suppliers of raw materials or other low-end products such as basic metals, chemicals, and fuels.

\section{Conclusion}

The Chinese experience with modernization and industrialization since Deng Xiaoping's auspicious 'opening' up of China in 1978 becomes all the more relevant for Africa given the multiple shortcomings and deficits identified in this account which hinder its growth and development. This has been overly concentrated on factor accumulation, especially

${ }^{63}$ UN Conference on Trade and Development, Fostering Africa's Services Trade for Sustainable Development. (Geneva: UNCTAD, 2015).

${ }^{64}$ UNECA, Industrializing Through Trade, pp. 101-124.

${ }^{65}$ Hannah Ryder, "Opinion: How can African countries get the most from Belt and Road," CGTN News, 18 May 2017.

https://news.cgtn.com/news/3d59444d7796b7a4d/share_p.html?from=timelime\&sappi/ accessed 5 June 2017. 
in the capital intensive and low productivity sectors. Moreover, employment creation has lagged behind and per capita growth has been lower than other developing countries because of high fertility rates. In this regard, we cannot emphasize enough the efficacy of viable industrial policy as veritable engines of growth in a global environment where developing countries lack autonomous policy space. As has correctly been observed: "Industrial policy-making in today's multilateral rule setting has become a significant challenge for developing countries". ${ }^{66}$

An important contribution that China can make to Africa's diversification is the outsourcing and relocation of its labor-intensive industries as well as low-skilled jobs to Africa, while developing more capital-intensive, high-tech industries within China. ${ }^{67}$ Furthermore, institutional upgrading needs to feature as an important component of this relationship. As we have observed, with more galvanized institutions, there is greater opportunity for African countries to increase their supply capacity and thereby broaden their production base. Institution-building and production relocation from China could do much for enhancing capabilities.

As Anderson et al. note: "It is likely that, in practice, Chinese firms would make their relocation decisions based on a variety of factors that include the business climate, country size, macroeconomic stability, and institutional development, among others". ${ }^{6}$ Hence, this will not be a blind decision or one driven by some necessity. For Anderson et al. such relocation would be a boon for the continent, "with significant gains across and improved linkages to the global economy."

As already noted, a major challenge which compounds the difficulty for many African countries to industrialize is the fact that, where it exists, Africa's manufacturing is dominated by small and informal enterprises that are not particularly productive. This significant presence of informality undermines the quotient of productivity. According to Rodrik, the decline in agricultural productivity in rural areas, and the resultant migration of labor to urban centres does not benefit manufacturing but rather the services sector. ${ }^{70}$ There are a number of conditions that African countries would need to fulfil in order to enhance their prospects of diversifying. These include building sound institutions, improving political and economic governance, developing human capital, supporting entrepreneurs, upgrading infrastructure especially energy, deepening regional integration as well as building regional value chains.

\footnotetext{
${ }^{66}$ UNECA, Transformative Industrial Policy for Africa, op. cit. p. 142.

67 Yun Sun, Africa in China's foreign policy, op. cit. p. 6.

${ }^{68}$ Derek Anderson et. al., "Spillovers from China onto Sub-Sahara Africa," op. cit. p. 25.

${ }^{69}$ Ibid., p. 5.

${ }^{70}$ Dani Rodrik, “An African Growth Miracle,” op. cit.
} 
African countries need to diversify their economies by way of prudential industrial policies and strategies. Export diversification is, according to the World Bank's Global Economic Prospects Report, associated with higher growth, and this should be thought of in both vertical (within sectors) and horizontal (beyond sectors) terms. ${ }^{71}$ There are African countries where the Chinese are developing tracks for green-field investments in manufacturing, pivoted on Special Economic Zones. These countries include Ethiopia, Nigeria, Ghana, and Tanzania. When President Muhammadu Buhari of Nigeria travelled to China on a state visit in April 2016, he received assurances of Chinese commitments to support Nigeria in areas such as improving production capacity, aviation, technology, infrastructure, and finance, together with a $\$ 6$ billion commitment towards power sector.

Rising labor costs in Asia could help the African continent make the leap toward industrial growth. This is a fortiori the case at this current juncture of structural shifts within China. Its rebalancing presents a window of opportunity for Africa but one that is bound to close sooner or later. African countries must embark on a pragmatic and workable reform agenda that is capable of driving increased productivity through value chains in the tradable sector. In addition, greater cooperation with China's private and public sectors through the FOCAC process could also be growth and welfare enhancing. In short, there is an overwhelming imperative for African countries to promote a progrowth environment. But African governments will first need to address a number of institutional deficits and competitive disadvantages that inhibit investment growth into diversified tradeable sectors. ${ }^{72}$ These include power constraints, poor transport infrastructure, opaque regulation, inflexible labor markets, weak contract enforcement, and policy uncertainty.

The decline in commodity prices took many African countries by storm and they were illprepared for the effects. This development has laid bare Africa's perennial problem relating to the lack of product and export diversification and its countries' heavy reliance on natural endowments rather than competitiveness imperatives. China's "new normal" associated with economic restructuring and addressing its excess manufacturing capacity offers Africa new opportunities to irrevocably move away from being the proverbial hewers of wood and drawers of water in regional and global value chains.

\footnotetext{
${ }^{71}$ World Bank, Global Economic Prospects: The Global Economy in Transition. Washington DC: World Bank, 2015), p. 54.

${ }^{72}$ Dani Rodrik, “An African Growth Miracle,” op.cit.
} 